\title{
深海生物チューブワームのへモグロビン
}

\section{高木 尚*}

\section{1.はじめに}

深海は光が届かない暗黒の世界である。そこには 光合成により炭素固定を行なう生物がいないので, 生物が棲息するのに必要な食物がない。従って, 深 海は生物の棲めない海の砂漠と考えられていた。 1977年アメリカの深海調查船アルビン号がガラパゴ 又島沖, 水深 $2600 x$ - ルの海底を調查中, 海嶺に 沿った熱水孔の周りに, 生物の群集を発見した。30 センチ程のシロウリ貝が海底をびっしりと埋め, そ の間を色素を失った白い蟹が, 動き回っている。更 にこれ迄見た事のない生物がいた。1メートル程の 細長い管状の先に二枚の真っ赤なえらの様な触手が ついている。これらが10本, 20本の群で立って, 頭 部の真っ赤な触手を熱水の噴出孔に近づけるように 摇れている。それは生物の棲めないと考えられてい た暗黒の深海に見出された生物のオアシスであった。

\section{2. アメリカでの深海生物の研究}

1) 形態, 分類 アルビン号の持ち帰った試料に ついて，アメリカでは深海生物のプロジェクトチー ムを作り研究に当たった。媣海で発見された管状の 生物は，その形状の示す通りチューブワーム (Tube Worm, 以下 TW と略す) と呼ばれる事となった。 TW は硬い管状の外款で覆われている。中には筒状 の柔らかい身体があるだけで, それが飛出さないよ うに触手の付け根の所を環状の筋肉が締めつけてい る[この筋肉をVest(ベスト，日本語ではチョッキ， 或いは羽織り)と呼ぶため TW の日本語としては八 オリムシの訳があるが，ここでは $\mathrm{TW}$ と呼ぶ]。そ してTWには口，消化器，こう門がなかった(図 1)。 この様な特異的な形態を示すため, TW はこれ迄に 記載されたどの動物にも属さないとされ，新しく Vestimentifera (衣類を着ているの意)という門を 作って分類された
TW はRiftia pachyptila（ガラパゴスハオリムシ） と命名された。

2) 栄養 口, 消化器, こう門のない TW は一体 どの様にして栄養物を得ているのであろうか。その 後の研究で, TWには体重のおよそ60\%を占める多 量の硫黄酸化細菌が共棲している事が分った。そし て熱水孔から噴出する硫化水素を TW が取入れ， それを共棲している硫黄酸化細菌に渡し, 細菌は硫 化水素を酸化，二酸化炭素を還元する事により，光 の無い状態で炭素固定を行ない, その細菌が合成し たものを TW は栄養物として得ている事が明らか となった ${ }^{2)}$ 。硫黄酸化細菌については, 共棲関係で はないが, 地上でも火山地帯の硫黄噴出孔附近で硫 化水素を取込み, 独立栄養生活をしている事は知ら れていた。深海ではそれが TW の中に共棲してい るだけとも言える。TW 以外, 深海の熱噴出孔に棲 むシロウリ貝にもやはり同じ様に硫黄酸化細菌が共 棲している。

3）硫化水素とへモグロビン 深海に棲む TW やシロウリ貝は酸素呼吸をしている。TW の先端に ある触手が真っ赤に見えるのは，中で循環している ヘモグロビン $(\mathrm{Hb})$ が透けて見えるためである。シ ロウリ貝も開けてみると真っ赤な体液が流れ出すが, これは体液中にある $\mathrm{Hb}$ の為であり，又この貝の筋 肉は赤く，その中にはミオグロビン $(\mathrm{Mb})$ が含まれ ている。この事は, これらの生物が酸素呼吸をして おり，その運搬系 $(\mathrm{Hb})$ も充分に発達している事を 示している。

酸素呼吸をしている生物にとっては, 硫化水素は 非常に猛毒である。これを共棲している細菌にいか にして運ぶかが問題であったが, 幾つかの研究を重 ねた後，TW の場合では $\mathrm{Hb}$ それ自身が硫化水素を 運搬する事が明らかとなった。即ち $\mathrm{Hb}$ は本来の酸 素を運搬する以外に, 硫化水素も結合するという事

*Takashi TAKAGI, 東北大学理学部生物学教室 (广980 仙台市青葉区荒巻字青葉)

Vol. 8, No.2 (1991) 


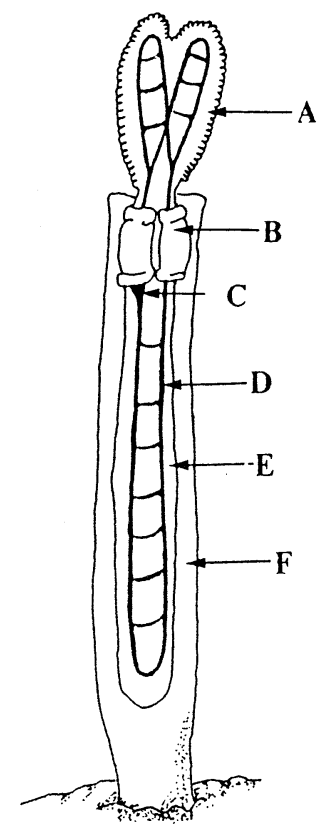

図 1 TW(R.pachyptila)の模式図 硬い管状 の外殼に覆われ先端のえら状の触手は, 血液が 透けて赤く見える。相模沖で採れた TW は触 手が何本かに枝分れしている。A：えら状の触 手, B : 環状の筋肉 (ベスト), C : 心蔵, D : 血管, $\mathrm{E}$ : 体腔, $\mathrm{F}$ : 外殼。

である。酸素はHbのへムに結合するが，硫化水素 は蛋白質即ちグロビンに結合し運搬される事が明ら かとなっだ)。

以上が我々が深海生物の研究に着手する前に既に アメリカで得られていた結果である。

\section{3. 日本での研究}

1) どの様にして始まったか アメリカのアルビ ン号が深海生物を発見したのが1977年であった。そ れから10年後, 1987年, 日本の“しんかい2000”が, 相模沖 $1130 \mathrm{~m}$ の梁海でシロウリ貝, TW の群集を 発見し, 採取した。相模沖で発見されるまでの10年 間, 哚海生物の研究はアメリカの独壇場であった。

1987年しんかい2000に乗込んでいたのは, 東大海 洋研の太田秀氏であった。彼の専門は海洋生態学で ある。従って陸に上がった彼がする事は, 取ってき たTW を解剖して，その形態を観察する事であっ た。その時に流れ落ちる真っ赤な血液が気になって
仕方がない。誰かこの様な海産生物の $\mathrm{Hb}$ をやって いる人はいないかと友人に相談して，紹介されたの が高知大・理・生物の鈴木知彦氏であった。彼は東 北大で $\mathrm{Hb}$ の一次構造を手掛け, 高知大に移ってか らも更に数多くの $\mathrm{Hb}, \mathrm{Mb}$ の構造を決定した。更 に一番の強みは世界に先駆けてゴカイ(イトメ)の細 胞外巨大 $\mathrm{Hb}$ の構造をほぼ完成させたところであっ た。というのも TW の場合も細胞外巨大 $\mathrm{Hb}$ であっ た事である。イトメは10月の産卵期には，海から河 口に一斉に押掛けるので, 簡単にバケツ数杯集めら れる。従って Hbの構造決定の際, ふんだんに材料 を使える事である。しかし TW の場合は量が限ら れている。

一方私は種々の蛋白質の一次構造をやっていたが, 苦労した末にやっと微量で構造決定できる装置を導 入し，その方法を確立した時期であった。そこで太 田氏が TW の採取, 鈴木氏が蛋白質, ペプチドを 分離, 私がその構造を決定する事にして, 共同研究 が始まった。

初めに断っておくが, アメリカのアルビン号が採 取したTW，Riftia pachyptilaは $1 \mathrm{~m}$ もある大き な物であったが，しんかい2000が相模沖で採取した $\mathrm{TW}$ は大きくて $30 \mathrm{~cm}$ 程度で, 形態も違っている。 一応 Lamellibrachia sp. とされているが, 種の同 定は未だされていない。

2) 目的 我々の目的はHbの構造を通して, (1)TWは本当に新たな門を作って分類するほどこれ 迄に発見された事のない新しい生物なのか,

(2)もしその様に新しい生物なら,これ迄記載されて いるどの生物と類縁関があるのか,

(3)硫化水素はどの様にして運ばれるのか，を明らか にする事であった。

3) サブユニットの構成 TW の Hb は環形動物 のそれと同じ様に, 細胞外 $\mathrm{Hb}$ である。細胞外 $\mathrm{Hb}$ の特徵は巨大分子であると云う事である。Hbをそ のままゲルろ過してみると図 2 に示すように $2 つ 0$ ピークに分れた4)。先に溶出されたピークAは環形 動物のHbの溶出位置と一致し, 分子量は 300 400 万であった。環形動物 $\mathrm{Hb}$ は，このピークしかない が，TW の場合それ以外に分子量44万に相当するピー クBが溶出される。Riftiaの結果では, 血液と体 腔液を別々に採取し，体腔液をゲルろ過するとピー ク Bのみが得られ，血液をゲルろ過するとピーク A と少量のピーク Bが現れる。この時ピーク Bの量は 採取毎に異なるが，これは血液を採取する際に，血 


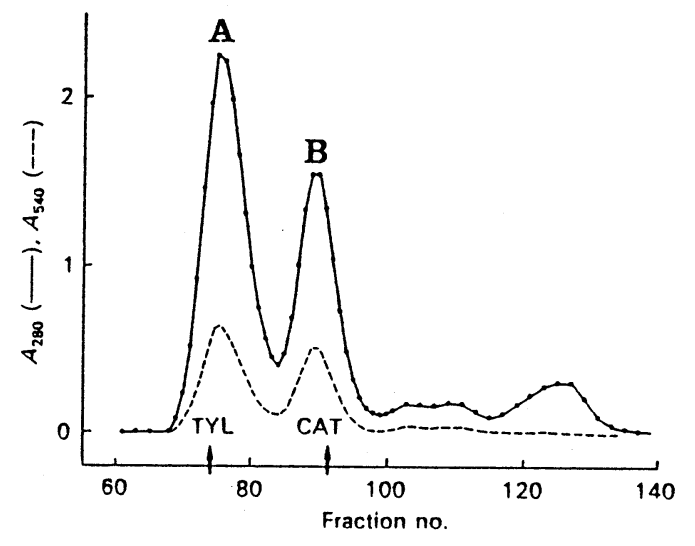

図 $2 H b$ のセファローズCL4B によるゲルろ 過 分子量マーカーは TYL : イトメの Hb (390 万), CAT : カタラーゼ(24万)。

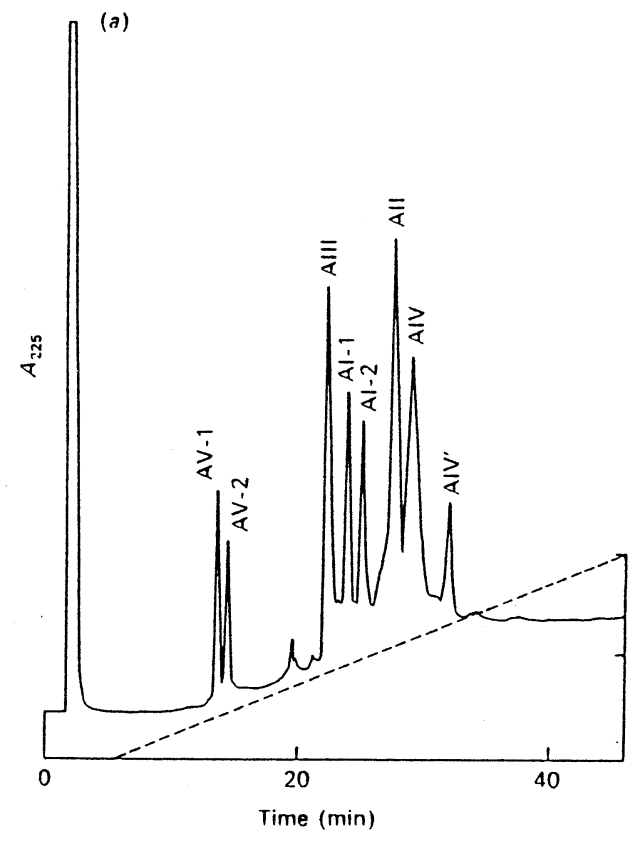

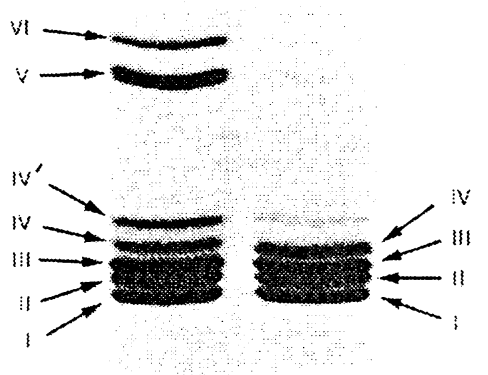

$\dot{A} \quad B$

図 $3 \mathrm{Hb}$ のメルカプトエタノール存在下での SDS-PAGE レーンA：図 2 のピークA,レー ン $\mathrm{B}:$ 図 2 のピーク $\mathrm{B}$ 。

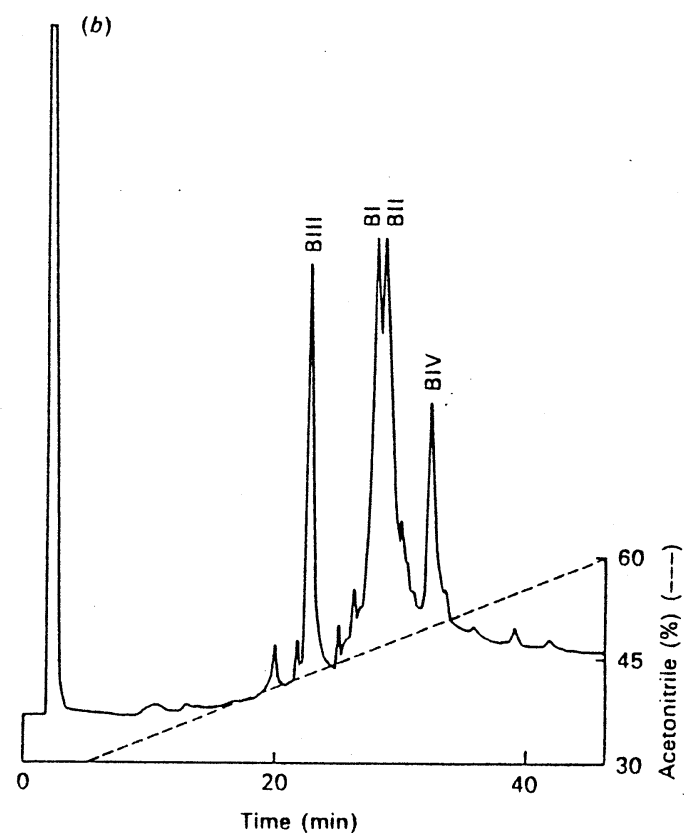

図 $4 \mathrm{Hb}$ サブユニットの HPLCによる分離 カラムはコスモシル $5 \mathrm{C}_{18}-300$, 溶媒は $0.1 \%$ トリフルオロ酶酸。試料は $6 \mathrm{M}$ グアニジン存在下で脱へム後, DTT で還元したのを直接 添加した。 $\mathrm{A}$ ：図 2 のピーク $\mathrm{A}, \mathrm{B}$ ：図 2 のピーク $\mathrm{B}$ 。 
液だけを集めるのは難しく, 常に体腔液が混入する ためと考えられる。従ってピークAは血液, ピーク Bは体腔液由来と考えてよい5)。我々の結果は血液 と体腔液の混合物である。

ピークA，Bの中身をSDS-PAGEで見てみると， 図 3 に示すような結果が得られた。Bには分子量 15 $\mathrm{kDa}$ 付近に 4 本のバンドが見られる。これは SDSPAGEによる分離であるが, 一次構造の結果から は分子量によって分離しているわけではない。移動 度の速い方から I から IV 迄の番号を与えてある。一 方 $\mathrm{A} に$ は, $\mathrm{B}$ と同じく $15 \mathrm{kDa}$ 付近に 5 本のバンド が見えるが，良く見るとバンドIVの量は，他のバン ド I - IIIに比べ少なくその上の IV'と合せて他のバ ンドと同じくらいになるように見えるので, $\mathrm{V}$ の番 号でなく, IN'とした。従って, A も $15 \mathrm{kDa}$ 付近の 蛋白質は B と同じく主に 4 種類のサブユニットから なり，その内の一つ(IV)にはバリエイションがある と考えて良いのではないだろうか。環形動物の場合 もやはり，15kDa に相当するサブユニットは 4 種 類からなり，これら 4 つともへムを持っている事が 明らかになっている。Aの場合には $15 \mathrm{kDa}$ 以外に, 分子量 $30 \mathrm{kDa}$ 付近に更に 2 本のバンド $(\mathrm{V}, \mathrm{VI})$ が 見える。これは非常に驚いた結果であった。それ迄 論争であったリンカー鎖の存在を示すものであった からである。このリンカー鎖の話については後で触 れる事にする。従ってBは 4 種類のへムを持つサブ エニットのみからなり, A はバリエイションはある が， 4 種類のへムを持つサブユニットと 2 種類のへ ムを持たないリンカー鎖からなっている事が明らか になった。

各サブユニットは, 逆相のカラムを用いて, 高速 液クロ (HPLC) で分離した(図 4)。Bでは, SDSPAGEで 4 本に分れたのと同様に 4 つのピークが 得られた。一方Aでは, SDS-PAGEで分れた以上 にピークが得られ, 調べてみると A I と A Vが更に 2 成分に分離した事が分った。 $\mathrm{A} V$ は溶出されなかっ だ!

4) サブュニットの中身 各サブユニットが分離 できたので, アミノ酸組成とN-末端からのアミノ 酸配列を分析してみると, $\mathrm{TW} の \mathrm{Hb}$ は他のどの生 物の $\mathrm{Hb}$ より, 環形動物の $\mathrm{Hb}$ に一番似ていること

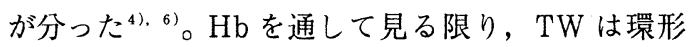
動物に非常に近い仲間ではないかと想像された。ま た AとBに共通しているサブユニットは, SDSPAGE での移動度, HPLCによる溶出位置, アミ
ノ酸組成,ならびに $\mathrm{N}-$ 末端からのアミノ酸配列分 析の結果から A II と B II， A II と B IIIである事が分っ た。またリンカー鎖 A V , A V V 配列は他のへムを 持ったサブユニットと類似が殆どない事が明らかと なった。

5) サブユニットのアミノ酸配列 TW は環形動 物に近いらしいと云う結果が出たので, これを確か めるため, また硫化水素がどの部位に付くのかを明 らかにするために, 各サブユニットの全構造を決定 する事にした。HPLC で分離しやすいA III (B III と 同じ)を決定し, 引続き B I , B II (A II と同じ), B IV および A V (リンカー鎖)の配列を決定した ${ }^{7)-9) 。 ~}$ ヘムを持ったサブユニットについての配列結果を環 形動物のと比較して図 5 に示してある。

この中で注目して戴きたいのは, システイン (C) の位置と数である。環形動物の 4 種類のへムを持っ ているサブユニットは, 1 つが単量体で, 残り 3 本 は分子間 S-S 結合により 3 量体を形成している。 そして 4 本とも分子内に $\mathrm{S}-\mathrm{S}$ 結合 (図 5 の 7 番と 141番のC) を持っておりフリーの SH 基は存在しな い(10)。システインだけを書き抜いて示したのが図 6 Aである。一方 TW の 4 種類のへムを持ったサブ ユニットは 2 本が単量体で, 残り 2 本が分子間 S$\mathrm{S}$ 結合により二量体を形成している。またサブユニッ トの中には, フリーの $\mathrm{SH}$ 基を持っているのがある 事が $\mathrm{SH}$ 基と反応する蛍光試薬での結果から分って (る ${ }^{6)}{ }^{7)}$ 。環形動物の分子内 $S-S$ 結合に関与して いる 7 番と141番のシステインは TWも全てのサブ ユニットで保存されている。従って, これらは分子 内 S-S 結合していると考えて良いであろう。また 環形動物の分子間の $\mathrm{S}-\mathrm{S}$ 結合に関与している132 番目のシスティンも B I 鎖と B II 鎖に保存されてい るので，これにより分子間 S-S 結合を形成し 2 量 体を作っていると考えられる。環形動物で 3 量体形 成に必要な 6 番目のシステインは, TW では他のア ミノ酸に置き換わっている。TW には更にB II 鎖の 71 番目と B III 鎖の 81 番に $\mathrm{S}-\mathrm{S}$ 結合に関与しないシ ステインがある(図 6 B)。この間で分子間 $S-S$ 結 合を形成していない事は, 一方は単量体で, もう片 方は 2 量体である事からも明らかである。従ってこ の 2 つシステインはフリーの SH 基を持っている 事になる。環形動物の $\mathrm{Hb}$ には硫化水素は結合しな い事が明らかになっている事, 環形動物と TW の $\mathrm{Hb}$ のアミノ酸配列の相同性, 違いを合せて考えて みると,これらの SH 基に硫化水素 $\left(\mathrm{H}_{2} \mathrm{~S}\right)$ が結合し 
Phe.I

TW. BI

TW. BIII

Lum.a

Lum.b

Ty1.I

Ty1.IIA

TW. BII

TW. BIV

Lum. C

Lum.d

Ty1.IIB

TY1.IIC

Phe.I

TW.BI

TW. BIII

Lum.a

Lum . b

Ty $1 . I$

TY1.IIA

TW. BII

TW. BIV

Lum. C

Lum.d

Ty1.IIB

TYI.IIC

Phe.I

TW. BI

TW.BIII

Lum. a

Lum. b

TY $1 . I$

TY1. IIA

TW. BII

TW. BIV

Lum. C

Lum. d

TY 1. IIB

Ty1. IIC
1

$\begin{array}{cc}10 & 20 \\ \text { DCNTLKRFKVKHQWQQVFSGE }\end{array}$ DCNILQRIKVKMQWAKAYGFG YECGPLQRLKVKRQWAEAYGSG ECLVTEGLKVKLQWASAFGHA KKQCGVLEGLKVKSEWGRAYGSG TDCGILQRIKVKQQWAQVYSVG SSDHCGPLQRLKVKQQWAKAYGVG 30 40 50 60 HHRTEFSLHFWKEFLHDHPDLVSLFKRVQGE AERAKFGNSLWTS I FNYAPDARELFDSVKSK NDREEFGHFIWTHVFKDAPSARDLFKRVRGD HQRVAFGLELWKGILREHPEIKAPFSRVRGD HDREAFSQAIWRATFAQVPESRSLFKRVHGD ESRTDFAIDVFNNFFRTNPD RSLFNRVNGD HERVELGIALWKSMFAQDNDARDLFKRVHGE SSNSCTTEDRREMQLMWANVWSAQF TGRRLAIAQAVFKDLFAHVPAAIGLFDRVHGT SKFCSEGDATIVIKQWNQI YNAGISAGSRLTMGNKI FSTLFKLKPESEALFSNVNVA DEHEHCCSEEDHRIVQKQWDI LWRDTESSKI KI GFGRLLLTKLAKDI PDVNDLFKRVDIE ADDEDCCSYEDRREIRHIWDDVWSSSF TDRRVAIVRAVFDDLFKHYPTSKALFERVKID DDCCSAADRHEVLDNWKGIWSAEF TGRRVAIGQAIFQELFALDPNAKGVFGRVNVD DTCCSIEDRREVQALWRSIWSAED TGRRTLIGRLLFEELFEIDGATKGLFKRVNVD

*

70

80

90

100

110

120

NIYSPEFQAHGIRVLAGLDSVIGVIDEDDTFTVQLAHLKAQHTER GTKPEYFDLFGTQL EMQSPQFKAHVARVIGGLDRVISMIDNAEALNADLEHLKSQHDPR GLDALNFAVFGKAL NIHTPAFRAHATRVLGGLDMCIALIDDEGVLNTQLAHLASQHSSR GVSAAQYDVVEHSV NIYSPQFGAHSQRVLSGLDITISMIDTPDMIAAQLAHLKVQHVER NLRPEFFDIFLKHL DTSHPAFIAHAERVLGGLDIAISTLDQPATLKEELDHLQVQHEGR KIPDNYFDAFKTAI ,NVYSPEFKAHMVRVFAGFDILISVLDDKPVIDQALAHYAAFHKQF GTIP FKAFGQTM DVHSPAFEAHMARVFNGLDRVISSLTDEPVLINAQLEHLRQQHIKL GITGHMFNLMRTGL DVNSNEFKAHCIRVVNGLDSAIGLLSDPSTLNDQLLHLATQHQERAGVTKGGFSAIAQSF NMSSGAFHAHTVRVLSGLDMGINYLNDAATLTSLTSHLATQHVARTGLKAVYFDAMGKVL HAEGPKFSAHALRI LNGLDLAINLLDDPPALDAALDHLAHQHEVREGVQKAHFKRFGEIL EPESGEFKSHLVRVANGLDLLINLLDDTLVLQSHLGHLADQH IQRKGVTKEYFRGIGEAF KPSEADWKAHVIRVINGLDLAVNLLEDPKALQEELKHLARQHRERSGVKAVY FDEMEKAL DTHSPEEFAH VRVVNGLDTLIGVLGDSDTLNSLIDHLAEQHKARAGFKTVYFKEFGKAL

$130 \quad 140 \quad 150$

FDILGDKLGTH FDQAAWRDC YAVIAAGIKPPP

FATVGGKFGV CFDLPAWESC YKVIAKGITGNDMFN

MMGVEHEIGQNVFDKDAWQAC LDVITGGIQGN

LHVLGDRLGTH FDFGAWHDC VDQIIDGIKDI

LHVVAAQLGR CYDREAWDAC IDHIEDGIKGHH

FQTIAEHIHG ADIGAWRACYAEQIVTGITA

AYVLPAQLGR CFDKEAWAACWDEVIYPGIKHD

LRVMPQVAS CFNPDAWSRC FNRITNGMTEGLA

MTVLPALID NFNPDAWRNC LLPLKSAIAEGLP

ATGLPQVLD DYDALAWKSC LKGILTKISSRLNA

ARVLPQVLS CFNVDAWNRC FHRLVARIARDLP

LKVLPQVSS HFNSGAWDRC FTRIADVIKAELP

NHVLPEVAS CFNPEAWNHC FDGLVDVISHRIDG

図 5 ヘムを持ったサブュニットのアミノ酸配列の比較 一番良く合うようコンピュータ で並べてある。全てに共通のアミノ酸には*印を, S-S 結合に関与するシステイン $(\mathrm{C})$ は小文字で, 硫化水素の結合に関与するC (71と81番)は下線で示した。Phe：シーボルト ミミズ (Pheretima sieboldi) ${ }^{21)}$, TW : チューブワーム (Lamellibrachia sp.) ${ }^{7), ~ 9), ~ L u m ~: ~}$

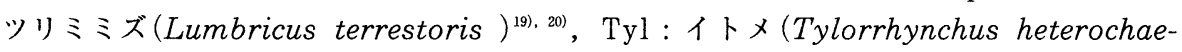
tus $)^{14)-17)}$ 。 

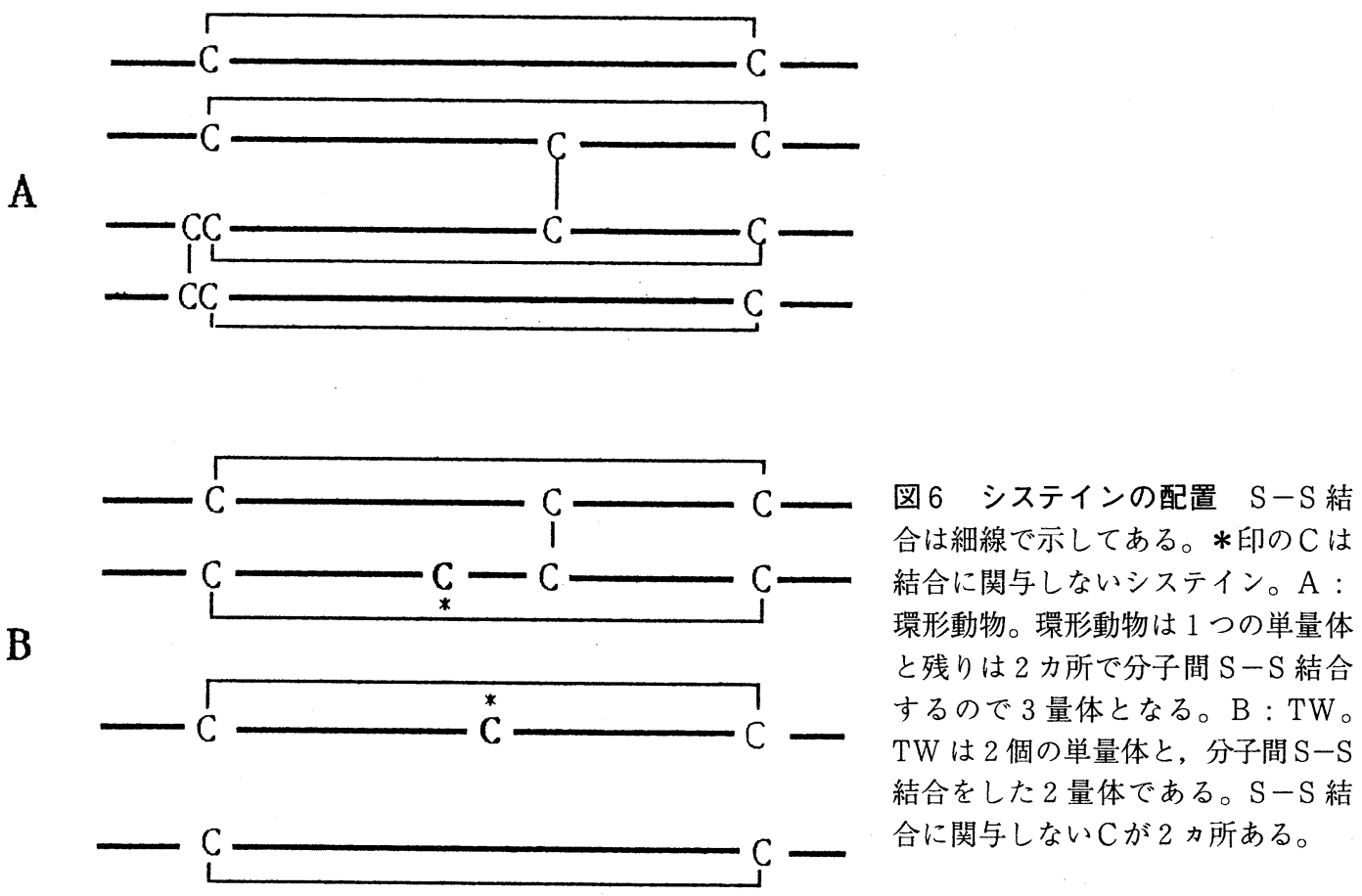

硫黄酸化細菌に運ばれると考えられるのではないだ ろうか。硫化水素は $\mathrm{SH}$ 基と共有結合を形成するの で,これを受け取る硫黄酸化細菌にも, 多分 SH 基 が関与するであろう受容体が存在するものと考えら れる。

6) 系統樹 図 5 では各鎖の相同関係がはっきり しないので, 配列の相同性に基づき系統樹で表した のが図 7 である。環形動物のミミズ, ゴカイ, それ に TW の 4 種類のサブユニットは，2つずつ A 型 とB型に分れる。この事は, 現在の 4 種類のサブユ ニットは元々は 1 つの共通の祖先から由来し, それ が遺伝子重複で, AとB型に分かれ, 更にその各々 が遺伝子重複を起こし 4 種類になったと考えられ る ${ }^{11)}$ 。TW の場合には, 未だアミノ酸配列は決定し ていないが, A I と A IVは 2 種類の成分からなって いる事から, 環形動物より更にもう一度遺伝子重複 が起きていると考えて良いであろう。

またこの系統樹から TW，ミミズ, ゴカイの 3 者 には全く差がない事が分かる。言い換えるとゴカイ は TWよりは同じ環形動物のミミズの方に似てい るとか, TW はミミズょりゴカイに似ている等とい う事はなく，3者とも等距離であるという事である。 即ち TW は, 環形動物のゴカイとミミズが分化す るのと同じ時期にそれらの共通の祖先から分化した
と考えられる。 $\mathrm{Hb}$ は非常に多くの生物で一次構造 が決定されており，それに基づいて上の様に系統樹 を作成してみると, 分類学で作成した系統樹と矛盾 していない事が分っている。我々が作成した Hbの 系統樹でこれ迄に分類学の系統樹に合わないはシロ ウリ貝のものだけである ${ }^{12)}{ }^{13)}$ 。・ヒト Hb の $\alpha$ 鎖と $\beta$ 鎖の相同性は $45 \%$ であり, 両者が分化したのは拉よ そ 5 億年前と考えられている。TW，ミミズ，ゴカ イの 3 者で似ている鎖同志のアミノ酸配列の相同性 を見ると 45-50\%である。従って，これらが共通の 祖先から分化した時期は掠よそ 5 億年前と考えて良 いのではないだろうか。

7) リンカー鎖 環形動物の $\mathrm{Hb}$ の研究の歴史は 古く, 超遠心機が開発された時, また電子顕微鏡が 開発された時, 巨大分子であるためにへモシアニン (Hc) と同梯に格好の材料として用いられた。それ 以来この巨大分子は何種類のサブユニットが何個集っ て出来ているのかというのは論争の的であった。 $\mathrm{Hc}$ の問題は別の機会に譲るとして, 環形動物の $\mathrm{Hb}$ は1980年代に入るとそれ迄超遠心, 電子顕微鏡, 電気泳動を用いての研究が中心であったが, 各サブ ユニットを分離して, それらの一次構造を決定し, それから全体を見直そうという方向に研究が変わっ てきた。日本では主に多毛類のゴカイ (Tylorrhyn- 


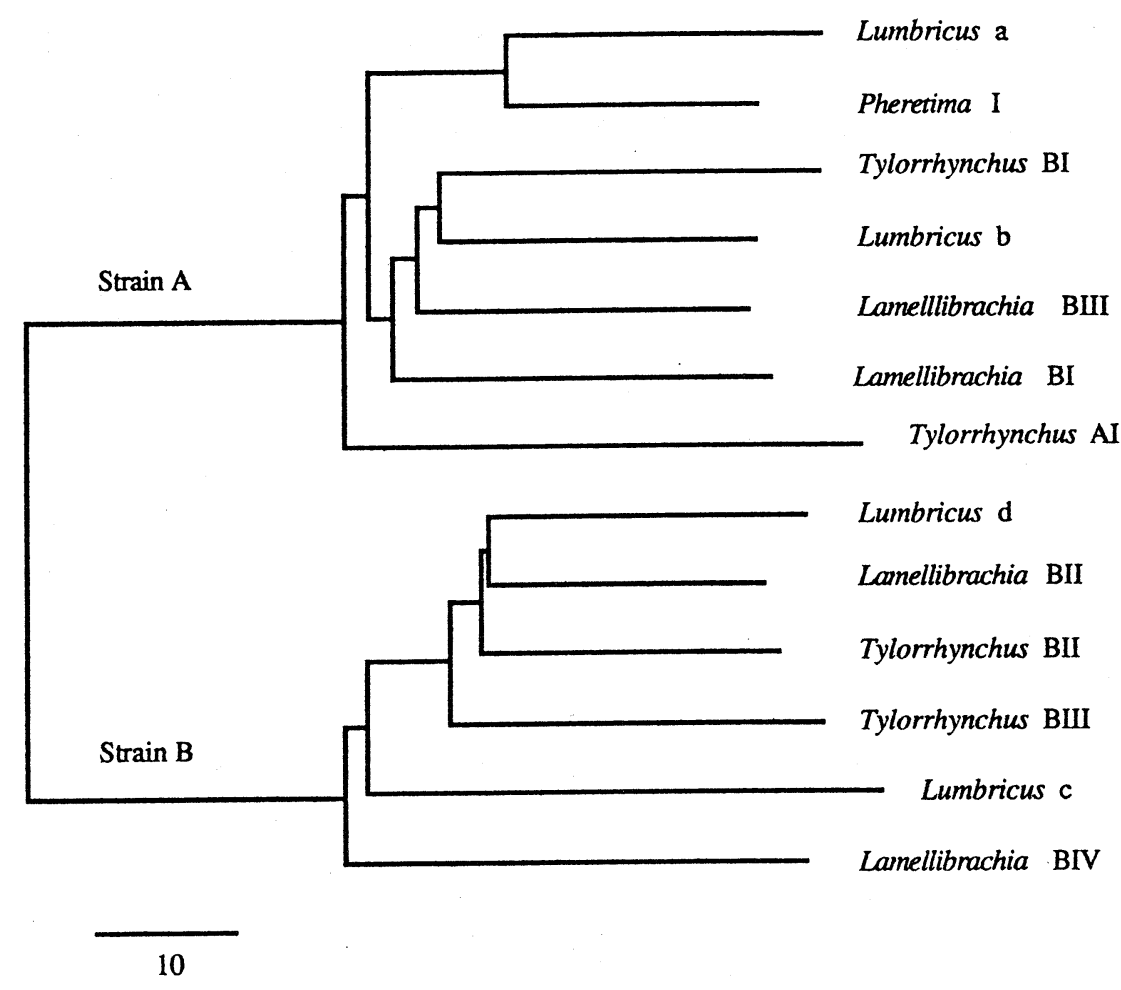

図 7 アミノ酸配列の相同性を元に作成した系統樹。種名に付いては図 5 を参照。図 5 及び系統樹はFeng と Doolittle ${ }^{30)}$ のアルゴリズムを用いてコンピュータで行なった。

chus heterochaetus)を，アメリカでは，貧毛類の ミミズ(Lumbricus terrestoris)を用いて, 各サブ ユニットが単離され，次々と構造が決定された ${ }^{14)-21)}$ 。 その結果, どちらも分子量 $15 \mathrm{kDa}$ 程度の 4 種類の サブエニットからなっている事が明らかとなった。 しかも 4 種類とも全てへムを持っていた。

古くから知られている事であるが, 環形動物の $\mathrm{Hb}$ の蛋白量と, へム含量の関係を求めると, 蛋白 質 $15 \mathrm{kDa}$ 当たりへム 1 個という值より常にへムの 值は小さく，この事から環形動物の $\mathrm{Hb}$ の中にはへ ムを持たないサブユニットが存在しそれがへムを持っ たサブユニットを繋いでいる, 即ちリンカー鎖が存 在するとされて来た。しかし各サブユニットを分離 後, 一次構造を決定した結果は, 全くリンカー鎖の 存在を打消すものであった。それでもなおリンカー 鎖の存在を主張し続けたグループがあった222。試料 は同じものを使っているのに彼等の結果では, 15 $\mathrm{kDa}$ のサブユニット以外に $30 \mathrm{kDa}$ の処にバンドが
見える。この様に一次構造の結果からはリンカー鎖 の存在は否定的であったが, 依然その存在を主張す るグループもあり，ある，ないの水掛け論に近い状 態であった。

そんな時に TW でリンカー鎖が明瞭に発見され， 更にその構造も決定されだ33。すでにTWと環形動 物の $\mathrm{Hb}$ は非常に良く似ている事が分っているから， 環形動物にもリンカー鎖は存在するであろう事は最 早決定的となった。そしてあるという事を確信して やるとやはり取れるものである。一次構造のグルー プがリンカー鎖を取れなかった原因は, 虫をすり潰 す際にEDTA を加えていたため, Ca あるいは $\mathrm{Mg}$ イオンが取除かれ，リンカー鎖が外れてしまったも のと考えられた。

ゴカイの場合, TW と同じく 2 種類のリンカー鎖 があるが, TW と異なりその各々が分子間 $\mathrm{S}-\mathrm{S}$ 結 合によりホモダイマーを形成している゙4) TW のリ ンカー鎖 $(\mathrm{AV})$ がゴカイのと違うところは, 糖を含 
んでいる事とフリーの SH 基を持っている事である。 この SH 基に硫化水素が結合すると考えられる。リ ンカー鎖は元々はへムを持っていたが遺伝子重複で 2 倍の長さになり, 最早へムを結合できなくなった と考えられる。へムを持ったサブユニットに比べア ミノ酸配列の相同性が低いのは, へムを結合すると いう制約が外れたために，突然変異を受入れやすく なった為と言えるのではないだろうか。リンカー鎖 の役割というのも未だ解明されていない。TW の場 合, 血液由来 $\mathrm{Hb}$ はリンカー鎖を持ち分子量400万 であり，体腔液由来 $\mathrm{Hb}$ はリンカー鎖を持たず分子 量44万である事が分っているので，この辺からリン カー鎖の役割の糸口が掴めるかもしれない。

8）TW と有䯮動物 TW は深海に棲み, 口, 消 化器, こう門がないという非常に特異的な生物に見 えるが, 果たしてこの様な生物は他にいないのだろ うか。殆どの生物は，20世紀にはいる前に記載され， 分類されている。ところが TW 以外たった一っ, 1900年になって初めて発見され, 新しく分類された 生物がある。それが有鬚動物 (ゆうしゅうどうぶつ, Pogonophora)である。何故この生物の発見が遅れ たかと云うのは，これが深海生物である事による。 1940年代以降はソヴィエト船が北太平洋の海底をド レッジして更に多くの種が発見された。深海底から ドレッジにより完全な形の有鼎動物を得るのは困難 であったが, 1964年にようやく完全な形で得る事に 成功した。有鬚動物は10-80センチほどの細長い生 物で, 硬い殼で覆われ, 先端に何本かの触手があり (これが䰅に見えるのでこの名前がある)，口，消化 器, こう門がない。栄養物は触手で海中の有機物を 吸収するのではないかとされているが，根拠はない。 それにしても有䰅動物と TW は良く似ているので はないだろうか。驚く事はない, TW も最初は有睗 動物に分類されたのだ。それがその後スミソニアン 博物館のジョーンズの研究により新しい門を作って 分類するようになったのだが25)，しかし，このジョー ンズの分類に分類学者が必ずしも賛成しているわけ ではないようである ${ }^{26)}$ 。では有䰅動物は分類上どん な位置にあるのか。日本の動物図鑑や, 分類学の本 では有鬚動物は奇妙な位置に分類されていて, 環形

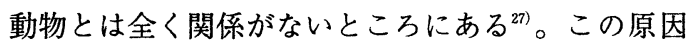
は有鬚動物が発見された当時, 原口動物か後口動物 かはっきりしなかったためと思われる。そしてどち らを取るかによって分類上の位置は全く違ってしま う。1964年完全の形で採る事に成功し, 調べてみる
と環形動物に特徴的な体節が有䰅動物のしっほ こ う呼んで良いかどうか分らないが)の先に見付かっ た。もちろん TWにもこの体節はある。この事か ら最近は環形動物に非常に近い位置に分類してい $b^{26)}$ 。

環形動物には海に棲んでいるゴカイの類(多毛綱), 淡水に棲むようになったヒルの類(ヒル綱), 更に陸 に上がり棲み出したミミズの類(筫毛綱)があるとさ れている。これ以外に日本の本ではユムシの類 (ב ムシ綱)も環形動物に入れてあるが27), 現在外して いるのが多い26) 28)。Hbから見てもユムシは細胞内 $\mathrm{Hb}$ であり ${ }^{29)}$, 細胞外 $\mathrm{Hb}$ を持つ有踷動物, $\mathrm{TW}$ 等 の方が環形動物に近いといえる。

\section{4.おわりに}

私たちは Hbを通して TW を見てきたが，これ迄 の結果から明らかなように有䰅動物の $\mathrm{Hb}$ に関する データがないのが一番痛いところである。しかし形 態的な類似性, 細胞外 $\mathrm{Hb}$ を持っていると云う事か ら私は TW は有䰅動物に入れても良いのではない かと思っている。そしてTWを入れた有䰅動物は 限りなく環形動物に近い。それはつい最近まで環形 動物門の中に分類されていたユムシ網より近い。 $\mathrm{Hb}$ で見る限り $\mathrm{TW}$ をれた有髹動物門は環形動物 門の中の有醬動物網になるのではないかと考えてい る。そして環形動物門の中の各網に分化する前の祖 先は細胞外 $\mathrm{Hb}$ を持っていて, その構成は既に 4 種 類のへムを持ったサブユニットと 2 種類のリンカー 鎖を持っていたと言える。その祖先から現在迄海水 に棲んでいる多毛綱，陸に上がった㙰毛綱，淡水に 棲むようになったヒル綱，それに深海に棲息するよ うになった有影綱が分化したと考えられるのではな いだろうか。その分化の時期は拉よそ 5 億年前と考 えられ，大陸が移動を始めた時期でもある。深海に 棲むようになった有䪹綱は光が届かない貧栄養の中 で, 硫黄酸化細菌と共棲生活のため硫化水素を運搬 する機能を獲得したに違いない。余り想像を広げる のは止めよう。深海生物の分子レベルでの研究は未 だ始まったばかりである。

この研究は東大 ・海洋研 ・太田秀氏, 高知大 ・ 鈴 木知彦氏, 東北大・岩浅央氏との共同研究で行なっ たものである。ここに感謝したい。 


\section{文献}

1) Jones,M.L.: Biol. Soc. Wash. Bull., 6, 117158 (1985)

2 ) Childress,J.J., Felbeck,H. \& Somero,G.N.: Sci. Am., 256, 106-112(1987)

3) Arp,A.J. \& Childress,J.J.: Science, 219, 295-297 (1983)

4 ) Suzuki,T., Takagi,T. \& Ohta, S.: Biochem. J., 255, 541-545(1988)

$5)$ Arp.A.J., Childress,J.J. \& Vetter,R.D.: J. Exp. Biol., 128, 106-112(1987)

6) Suzuki,T., Takagi,T., Okuda,K., Furukohri, T. \& Ohta,S.: Zool. Sci., 6, 915-926(1989)

7 ) Suzuki,T., Takagi,T. \& Ohta,S.: Biochem. J., 266, 221-225 (1990)

8) Suzuki,T., Takagi,T. \& Ohta,S.: J.Biol. Chem., 266, 1551-1555(1990)

9) Takagi,T., Iwaasa,H., Ohta,S. \& Suzuki, T.: Structure and Function of Invertebrate Oxygen Carries (Vinogradov, S.N. ed.)

Escom Sci. Publishers, B. V., The Netherlands. pp. 247-252(1991)

10) Suzuki,T., Kapp,O.H. \& Gotoh,T.: J.Biol. Chem. 263, 18524-18529(1988)

11) Gotoh,T., Shishikura,F., Snow,J.W., Ereifej,K. \& Vinogradov,S.N.: Biochem.J., 241, 441-445 (1987)

12) Suzuki,T., Takagi,T. \& Ohta,S.: Biochem. J., 260, 177-182 (1989)

13) Suzuki,T., Takagi,T. \& Ohta,S.: Biochim. Biophys. Acta, 999, 254-259 (1989)

14) Suzuki,T., Takagi,T. \& Gotoh,T.: Biochim. Biophys. Acta, 708, 253-258(1982)

15) Suzuki,T., Furukohri,T. \& Gotoh,T.: J. Biol.Chem., 260, 3145-3154(1985)
16) Suzuki,T., Yasunaga,H., Furukohri,T., Nakamura,K. \& Gotoh,T.: J.Biol.Chem., 260, 11481-11487 (1985)

17) Suzuki,T. \& Gotoh,T.: J.Biol.Chem., 261, 9257-9267 (1986)

18) Shishikura,F., Snow,J.W., Gotoh,T., Vinogradov,S.N. \& Ẉalz,D.A.: J.Biol.Chem., 267, 3123-3131(1987)

19) Fushitani,K., Matsuura,M.S.A. \& Riggs, A.F.: J.Biol.Chem., 263, 6502-6517(1988)

20) Suzuki,T.: Eur. J.Biochem., 185, 127-134 (1989)

21) Jhiang,S.M., Garey,J.R . \& Riggs,A.F.: Science, 240, 334-336 (1988)

22) Vinogradov,S.N., Lugo,S.D., Mainwaring, M.G., Kapp,O.H. \& Crewe,A.V.: Proc. Natl. Acad. Sci. (USA), 83, 8034-8038(1986)

23) Suzuki,T., Takagi,T. \& Ohta,S.: J.Biol. Chem., 265, 1551-1555(1990)

24) Suzuki,T., Takagi,T. \& Gotoh,T.: J.Biol. Chem., 265, 12168-12177(1990)

25) Jones,M.L.: The origins and relationship of lower invertebrates (Morris,S.C., George, J.D., Gibson,R. \& Platt,H.M., ed.) Oxford Univ. Press, Oxford, pp. 327-342(1985)

26) Barnes,R.D.: Invertebrate Zoology (4th ed.) Saunder Colleges, Philadelphia \& Holt-Saunders, Tokyo (1980)

27）新編日本動物図鑑，北隆館 (昭和54年)

28) Pearse,V., Pearse,J., Buchsbaum,M: \& Buchsbaum,R.: Living Invertebrate, Boxwood Press, CA (1987)

29) Gerey,J.R. \& Riggs,A.F.: J.Biol.Chem., 261, 16446-16450(1986)

30) Feng,D.-F. \& Doolittle,R.F.: J.Mol. Evol., 25, 351-360 (1987) 